\title{
Exogenous proline and hormone in combination with compost improves growth and tolerance of maize under heavy metal stress
}

\author{
Sifau A. Adejumo*, Vitoria Awoyemi and Adeniyi O. Togun \\ Environmental Biology Unit, Department of Crop Protection and Environmental Biology, Faculty of Agriculture, \\ University of Ibadan, Ibadan, Nigeria \\ *Corresponding Author: nikade_05@yahoo.com
}

\begin{abstract}
Abiotic stress such as heavy metal contamination of agricultural soil limits crop production by disrupting plant's physiological activities and seed germination. Exogenous proline, hormone and compost have been used to induce growth and stress tolerance in crop but little is known about their interactive and anti-oxidative roles in crop exposed to heavy metal stress. This study assessed the effects of pre-sowing seed soaking with exogenous proline $(\mathrm{P})$ and hormones (Gibberellic acid; GA and Indole-acetic acid; IAA) on the $\mathrm{Pb}$ accumulation, osmolytes (P, phenolics; $\mathrm{PH}$ and Glycine betaine; GB), Photosynthetic pigments (chlorophyll and carotenoids) and stress indexes $\left(\mathrm{H}_{2} \mathrm{O}_{2}\right.$ and malonialdehyde; MDA) of maize grown on compost amended $\mathrm{Pb}\left(23,959 \mathrm{mg} \mathrm{kg}^{-1} \mathrm{~Pb}\right)$ contaminated soil. Compost was applied at $20 \mathrm{t} \mathrm{ha}^{-1}$ and $40 \mathrm{t} \mathrm{ha}^{-1}$, P, GA and IAA were applied at $10 \mathrm{mM}$ and $5 \mathrm{mM}$ solely and in combinations to give a total of 34 treatments including control (Distilled water only) and replicated 3 times. Except in IAA treatment, seed pre-treatments with exogenous $\mathrm{P}$ and GA and soil amendment with compost generally enhanced chlorophyll production in maize and reduced $\mathrm{GB}$, carotenoids, $\mathrm{H}_{2} \mathrm{O}_{2}$ and MDA in treated seeds compared to control. With regards to stress indexes $\mathrm{G} 2+\mathrm{C} 1$ gave the lowest values. Sole application of P1, P2, C2, G1 and I2 enhanced the production of proline in treated plants compared to

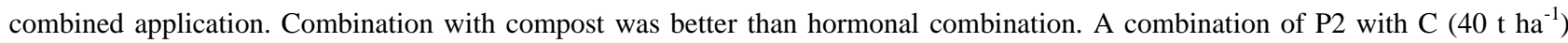
(P2C2) gave the maximum chlorophyll content and reduced the endogenous GB and P. Treatment with $\mathrm{P} 2 \mathrm{C} 2$ also reduced $\mathrm{Pb}$ accumulation in plant. In conclusion, exogenous application of hormones and proline in combination with organic amendment induces heavy metal tolerance in maize and increased protection against oxidative stress compared to contaminated control. The technique that can enhance crop growth on contaminated soil, reduce metal uptake and provide osmo-protection could be a promising approach.
\end{abstract}

Keywords: Contamination, Hormones, Osmolytes, Organic amendment, Seed soaking, Heavy metals.

\section{INTRODUCTION}

Soil contamination with heavy metals is one of the abiotic stresses that cause a reduction in crop production (Sandalio et al., 2001). They affect plant physiological processes and induce production of Reactive Oxygen Species (ROS) that cause oxidative damage and lipid peroxidation (Eun et al., 2000; Siedlecka \& Krupa, 2002; Verma \& Dubey, 2003; Souguir et al., 2011). The contamination of agricultural lands from different anthropogenic sources is most worrisome. Apart from reducing the amount of cultivable lands, it increases the risk of animal and human contamination with toxic heavy metals through food chain and poses a threat to food security. Heavy metal also causes reduction in photosynthesis and retard crop growth by competing with essential mineral nutrients and inducing phytotoxicity (Siedlecka, 1995; Sharma \& Dubey, 2005, 2007). Different efforts have been made to remediate heavy metal contaminated soils (Adejumo et al., 2010) but none of the strategies proposed can give complete remediation. The development of metal-tolerant plants has also not been possible due to the complexity of the procedures involved. There is need therefore, for the development of simple and cost-effective methods for containing the contaminants, reduce/prevent plant uptake and enhance crop tolerance.

Though the use of immobilizing agents to reduce metal solubility has been used effectively for reducing metal uptake by cultivated crops (Adejumo et al. 2010, Salati et al. 2010, Adejumo et al. 2018a) but, the first challenge in crop production on contaminated soil is seed germination and seedling development. Seed germination is the most crucial step in plant's life cycle that ensures the survival of the next generation. If these hurdles can be overcome, plants have natural inbuilt ability to induce anti-oxidative mechanisms that can be used for survival in the face of different environmental challenges (Hossain et al., 2012). In this regard, the technique that can stimulate seed germination, induce seedling development, reduce metal uptake, ensure nutrient availability for crop development and provide osmoprotection could be an acceptable and comprehensive method for enhancing crop tolerance to heavy metal toxicity.

Seed priming technique with osmo-protectants and growth elicitors like hormones have been implicated in the activation of some pre-germination metabolic processes and stress tolerance inducement (Tsegay \& Andargie, 2018). 
Proline, an amino acid that participate in the osmotic adjustment of plant cells under stress has been reported to improve plant resistance to oxidative stress induced by heavy metal toxicity by scavenging ROS (Martins et al., 2011; Hossain et al., 2012; Adejumo et al., 2015). Similarly, plant hormones which are chemical substances produced by the plant to stimulate growth and development (Zhang et al., 2007) are also involved in signaling activity for inducing plant stress responses (Iqbal \& Ashraf, 2013). Plants' responses to environmental stresses have also been reported to include up or down-regulation of phytohormones (Ishii et al., 2010; Strader et al., 2010). Similarly, positive responses to exogenous application of hormones have been reported (Yuan \& Xu, 2001; Ashraf et al., 2002; Iqbal \& Ashraf, 2013). Gibberellic acids (GAs) and ABA are a group of plant growth hormones generally reported to be involved in the abiotic stress tolerance and developmental processes (Yuan \& Xu, 2001; Magome et al., 2004; Iqbal \& Ashraf, 2013). Gibberellin is known for seed germination while auxin hormone has been reported to induce rooting especially in stem cuttings when exogenously applied and induce synthesis of endogenous cytokinnin (Zhang et al., 1995; Camolesi et al., 2007; Singh \& Khan, 2009; Wang et al., 2009). Their effectiveness however, varies depending on the concentration and interactions with other treatments.

Uptake, transport and accumulation of metal by plant are strongly influenced by soil conditions and activities taking place at the root zone (Bolan et al., 2008; Adejumo et al., 2018b). The uptake of $\mathrm{Pb}$ for instance, is especially influenced or determined by the level of organic matter in the soil (Adejumo et al., 2010, 2011, 2012, 2018c). Presowing seed treatments with an osmoprotectant like proline and growth regulators to induce tolerance and germination could be a promising approach to enhance crop growth on contaminated soil and ameliorate abiotic stress in crop plants. This can then be coupled with soil amendment with organic materials like compost to immobilize heavy metals in the soil (Adejumo et al., 2011). In our previous study, seed germination, maize growth and yield, as well as duration of survival, responded positively to proline, hormone and compost treatments (Awoyemi \& Adejumo, 2018). Under this study, osmolytes production, photosynthetic pigments and oxidative stress tolerance of maize crop in response to presowing seed soaking with hormones and proline were investigated. Understanding the anti-oxidative roles and the interplay between exogenous proline, hormones and compost on crop will guide in the development of appropriate strategies for enhancing crop tolerance to heavy metal stress and ensuring food security.

\section{METHODOLOGY}

\section{Sources of soil used for the experiment}

The study involved the use of contaminated soil and this was obtained from battery wastes dump site, Lalupon, Ibadan, Nigeria while the normal (uncontaminated) soil used as control was obtained from the crop garden of the Department of Crop Protection and Environmental Biology, University of Ibadan, Ibadan, Nigeria. The contaminated site was the dumpsite of the defunct Lead-acid Battery manufacturing company (Adejumo et al., 2011). Top soil was collected from five equidistant points on the contaminated site and thoroughly mixed together before packing them in the sacs. The soil was first air-dried and sieved using $2 \mathrm{~mm}$ mesh. The composite sample was then taken for heavy metal analysis following standard procedure and the $\mathrm{Pb}$ concentration was $23,959.00 \mathrm{mg} \mathrm{kg}^{-1}$ in contaminated soil.

\section{Experimental treatments and design}

Compost was prepared from Mexican sunflower and poultry manure following the procedure of Akanbi (2002) and Adejumo et al., (2010) while, proline, giberrellic acid and indole-acetic acid were obtained from the chemical store. As described in Awoyemi \& Adejumo (2018), for this experiment, the treatments were denoted as Compost (C), Proline (P), Gibberellic acid (G) and Indole-acetic acid (I) and were applied using two rates. Compost was applied at $20 \mathrm{tha}^{-1}$ and $40 \mathrm{tha}^{-1}$ while proline and hormones were applied at $10 \mathrm{mM}$ and $5 \mathrm{mM}$ as sole $(\mathrm{C} 1, \mathrm{C} 2, \mathrm{I} 1, \mathrm{I} 2, \mathrm{P} 1, \mathrm{P} 2, \mathrm{G} 1, \mathrm{G} 2$,) and combined $(\mathrm{I} 1+\mathrm{G} 1, \mathrm{I} 1+\mathrm{G} 2, \mathrm{I} 1+\mathrm{P} 1, \mathrm{I} 1+\mathrm{P} 2, \mathrm{I} 2+\mathrm{G} 1, \mathrm{I} 2+\mathrm{G} 2, \mathrm{I} 2+\mathrm{P} 1, \mathrm{I} 2+\mathrm{P} 2, \mathrm{G} 1+\mathrm{P} 1, \mathrm{G} 1+\mathrm{P} 2, \mathrm{G} 2+\mathrm{P} 1, \mathrm{G} 2+\mathrm{P} 2, \mathrm{I} 1+\mathrm{C} 1, \mathrm{I} 1+\mathrm{C} 2$, $\mathrm{I} 2+\mathrm{C} 1, \mathrm{I} 2+\mathrm{C} 2, \mathrm{G} 1+\mathrm{C} 1, \mathrm{G} 1+\mathrm{C} 2, \mathrm{G} 2+\mathrm{C} 1, \mathrm{G} 2+\mathrm{C} 2, \mathrm{P} 1+\mathrm{C} 1, \mathrm{P} 1+\mathrm{C} 2, \mathrm{P} 2+\mathrm{C} 1, \mathrm{P} 2+\mathrm{C} 2)$ applications to give a total of 34 treatments including control (Distilled water only) and replicated 3 times using Completely Randomized Design. Hormones and proline were prepared based on their molecular weights as explained by Awoyemi \& Adejumo (2018). Seed soaking procedure was carried out according to the procedure of Hanan et al. (2013) and adopted by Awoyemi \& Adejumo (2018). Plastic pots were filled with $1 \mathrm{~kg}$ each of both contaminated and uncontaminated soils and compost was applied to the pots that were receiving compost treatments two weeks before planting to ensure proper mineralization. Each pot was sown with four seeds of maize (DTMR). The emerging seedlings were thinned down to 2 after emergence and the soil was watered moderately till the end of the experiment which lasted for 8 weeks.

\section{Determination of chlorophyll and carotenoid}

The extraction was done using the method described by Sarropoulou et al. (2012). The absorbance of Chlorophylls a and b were measured at 665 and $649 \mathrm{~nm}$ respectively while Carotenoids was measured at 440nm using UV/VIS 
Spectrophotometer (Spectrumlab 752s Ningbo, China). Total chlorophyll and Carotenoid were determined using the equation below:

$$
\text { Chlorophyll }(\mathrm{a}+\mathrm{b})=(6.10 \mathrm{xA} 665+20.04 \mathrm{xA} 649) \times 10 / 1000 / \mathrm{F} . \mathrm{W}(\mathrm{mg} / \mathrm{g} \mathrm{F} . \mathrm{W})
$$

Carotenoid = (4.69x A440 - $1.96 \times$ A665 - 4.74 x A649) $\mathrm{x}$ volume of supernatant (10 ml) $\mathrm{x}$ dilution factor/ 0.1

\section{Determination of Proline, glycine betaine and total phenolics}

Proline was estimated in the plant leaves according to Bates et al. (1973) using acid-ninhydrin method and the red colour intensity was measured at $520 \mathrm{~nm}$. Leaf Glycine betaine was determined following the procedure described by Grieve \& Grattann (1983) and the organic layer measured at $365 \mathrm{~nm}$. Total phenolics was determined following Julkunen-Titto (1985) procedure using Folin Ciocalteaus and was read at $750 \mathrm{~nm}$ and results expressed as $\mathrm{mg}^{-1}$ of fresh leaf weight using UV/VIS Spectrophotometer (Spectrumlab 752s Ningbo, China).

\section{Hydrogen peroxide $\left(\mathrm{H}_{2} \mathrm{O}_{2}\right.$ and Malononyldialdehyde (MDA) contents Determination}

The hydrogen peroxide in the plants was determined following Chanda (2012) procedure while the protocol suggested by Velikova et al. (2000) was used for MDA determination, with some modifications. Tissue material (500 $\mathrm{mg}$ ) was grinded with sand in a mortal containing $5 \mathrm{ml}$ of $0.1(\mathrm{w} / \mathrm{v})$ trichloroacetic acid (TCA) solution. The homogenate was centrifuged at $10,000 \mathrm{x}$ g for 20 minutes and $1 \mathrm{ml}$ of the supernatant was divided into two eppendorph tubes as $0.5 \mathrm{ml}$ per tube. Then, $1 \mathrm{ml}$ of $0.5 \%$ (w/v) Thiobabituric (TBA) in 20\% TCA solution was added into these aliquots and they were incubated at $96^{\circ} \mathrm{C}$ for 30 minutes. The reaction was stopped by placing the reaction tubes in an ice bath for 5 minutes and then centrifuged at $10,000 \mathrm{x} \mathrm{g}$ for 5 minutes. The absorbance of the supernatants was monitored at $532 \mathrm{~nm}$. The amount of MDA - TCA complex was calculated from the extinction coefficient of $155 \mathrm{mM}^{-}$ ${ }^{1} \mathrm{~cm}^{-1}$.

\section{Analysis for Pb concentration in soil and plant}

Soil $\mathrm{Pb}$ concentration before and after planting was analyzed according to the method described by Ogundiran (2007). The filtrates were made up to $100 \mathrm{ml}$ in a standard flask and were read for $\mathrm{Pb}$ concentration using Atomic Absorption Spectrophotometer (VGP210 BUCK Scientific Model). Plant analysis for Pb concentration was carried out at harvesting using dry ashing method and $\mathrm{Pb}$ concentration was determined in the final filtrate using Atomic Absorption Spectrophotometer (VGP210 BUCK Scientific Model).

Data were analyzed using ANOVA of DSASSTAT version 2012. Means were separated using Duncan Multiple Range Test (DMRT) at $\mathrm{p}<0.05$.

\section{RESULTS}

Effects of sole application on photosynthetic pigments, proline, glycine betaine, phenolics and stress indexes $\left(\mathrm{H}_{2} \mathrm{O}_{2}\right.$ and MDA) of maize grown on Pb contaminated soil

Table 1. Effect of sole application of different concentrations of proline, hormones and compost on photosynthetic pigments, stress indexes $\left(\mathrm{H}_{2} \mathrm{O}_{2}\right.$ and MDA), phenolics, proline and glycine betaine contents of maize grown on $\mathrm{Pb}$ contaminated soil.

\begin{tabular}{llllllll}
\hline Treatments & CHL & CRD & GB & PHNL & PROLINE & MDA & $\mathbf{H}_{2} \mathbf{O}_{2}$ \\
\hline C1 & $2.741 \mathrm{e}$ & $797.813 \mathrm{~b}$ & $0.768 \mathrm{~d}$ & $0.713 \mathrm{c}$ & $0.25 \mathrm{bcd}$ & $0.046 \mathrm{c}$ & $0.403 \mathrm{c}$ \\
$\mathbf{C 2}$ & $2.699 \mathrm{e}$ & $800.07 \mathrm{a}$ & $0.456 \mathrm{f}$ & $0.926 \mathrm{~b}$ & $0.54 \mathrm{~d}$ & $0.016 \mathrm{c}$ & $0.401 \mathrm{c}$ \\
P1 & $5.459 \mathrm{a}$ & $618.054 \mathrm{i}$ & $1.099 \mathrm{c}$ & $0.314 \mathrm{e}$ & $0.363 \mathrm{bcd}$ & $0.03 \mathrm{c}$ & $0.596 \mathrm{~b}$ \\
P2 & $3.243 \mathrm{~d}$ & $641.306 \mathrm{~h}$ & $0.715 \mathrm{de}$ & $0.91 \mathrm{~b}$ & $0.386 \mathrm{ab}$ & $0.011 \mathrm{c}$ & $0.517 \mathrm{bc}$ \\
$\mathbf{G 1}$ & $1.692 \mathrm{f}$ & $744.686 \mathrm{f}$ & $0.587 \mathrm{ef}$ & $0.478 \mathrm{~d}$ & $0.472 \mathrm{a}$ & $0.597 \mathrm{a}$ & $0.34 \mathrm{c}$ \\
G2 & $3.98 \mathrm{~b}$ & $790.813 \mathrm{c}$ & $0.543 \mathrm{f}$ & $0.615 \mathrm{~cd}$ & $0.196 \mathrm{~cd}$ & $0.26 \mathrm{~b}$ & $0.777 \mathrm{a}$ \\
$\mathbf{I 1}$ & $3.125 \mathrm{~d}$ & $778.86 \mathrm{~d}$ & $1.272 \mathrm{~b}$ & $1.11 \mathrm{a}$ & $0.174 \mathrm{~d}$ & $0.035 \mathrm{c}$ & $0.376 \mathrm{c}$ \\
I2 & $2.825 \mathrm{e}$ & $711.481 \mathrm{~g}$ & $1.174 \mathrm{bc}$ & $0.557 \mathrm{~cd}$ & $0.385 \mathrm{ab}$ & $0.04 \mathrm{c}$ & $0.709 \mathrm{a}$ \\
CNS & $5.566 \mathrm{a}$ & $598.858 \mathrm{j}$ & $0.883 \mathrm{~d}$ & $0.516 \mathrm{~d}$ & $0.178 \mathrm{~d}$ & $0.115 \mathrm{bc}$ & $0.335 \mathrm{c}$ \\
CLCS & $3.597 \mathrm{c}$ & $751.638 \mathrm{e}$ & $1.488 \mathrm{a}$ & $0.57 \mathrm{~cd}$ & $0.241 \mathrm{bcd}$ & $0.052 \mathrm{c}$ & $0.461 \mathrm{bc}$ \\
\hline
\end{tabular}

Note: $\mathrm{C}=$ Compost, $\mathrm{P}=$ Proline; $\mathrm{G}=$ Gibberellic acid; $\mathrm{I}=$ Indole acetic acid; $\mathrm{CNS}=$ Control uncontaminated soil; $\mathrm{CLCS}=$ Control contaminated soil, $1=$ Concentration at $5 \mathrm{mM}$ and rate at $20 \mathrm{tha}^{-1}, 2=$ Concentration at $10 \mathrm{mM}$ and rate at $40 \mathrm{tha}^{-1}$.

On the effect of the sole application on total chlorophyll contents of maize, it was observed that the application of proline at a lower rate performed better than other treatments including uncontaminated treatment. This was followed by those pre-treated with G2 and those planted on uncontaminated soil (CNS) while maize treated with G1 had the least chlorophyll content (Table 1). Carotenoid, unlike chlorophyll, was low in the maize pretreated with $\mathrm{P}$ compared to other treatments. Maize planted on soil amended with compost had the highest value but not different from hormone treatments. This was followed by that of maize grown on contaminated control (CLS) and treatment with G2. Similar to what was observed for carotenoid, glycine betaine was reduced in response to seed pretreatment with proline and 
hormone as well as soil amendment with compost. Maize pre-treated with $\mathrm{G}$ had the lowest while maize planted on contaminated soil only had the highest. Compared to the control plants (Distilled water), sole application of P1, P2, C2, G1 and I2 enhanced the production of proline in treated plants compared to untreated seeds in contaminated control. The lowest value of proline was recorded in maize planted on uncontaminated soil. Seed pretreatment with I1 gave the highest concentration of phenolics in maize leaf compared to other treatments. This was followed by those pre-treated solely with P2 and C2 while it was low in maize pre-treated with P1. On hydrogen peroxide content, the highest value was recorded in maize pre-treated with G2 followed by those of I2. Surprisingly, the lowest value was recorded in maize grown on control soil followed by those pre-treated with a lower rate $(5 \mathrm{mM})$ of hormone and those grown on soil treated with $\mathrm{C} 1$ and $\mathrm{C} 2$. Malonylaldehyde (MDA) value was reduced in maize pre-treated with $\mathrm{P} 2$ but was high in maize pre-treated with I1 followed by that of G2 (Table 1).

\section{Photosynthetic pigments, proline, glycine betaine, phenolics and stress indexes $\left(\mathrm{H}_{2} \mathrm{O}_{2}\right.$ and MDA) of maize grown on $P b$ contaminated soil as affected by combined application of proline and hormone without compost}

Table 2. Effect of combined application of different concentrations of proline and lower rate of hormones on photosynthetic pigments, stress indexes $\left(\mathrm{H}_{2} \mathrm{O}_{2}\right.$ and MDA), phenolics, proline and glycine betaine contents of maize.

\begin{tabular}{llllllll}
\hline Treatments & CHL & CRD & GB & PHNL & PROLINE & MDA & $\mathbf{H}_{\mathbf{2}} \mathbf{O}_{2}$ \\
\hline P1I1 & $4.494 \mathrm{~b}$ & $331.065 \mathrm{~h}$ & $0.97 \mathrm{c}$ & $0.715 \mathrm{~b}$ & $0.316 \mathrm{bc}$ & $0.048 \mathrm{ab}$ & $0.586 \mathrm{~cd}$ \\
P2I1 & $3.667 \mathrm{~d}$ & $666.463 \mathrm{e}$ & $0.989 \mathrm{c}$ & $0.173 \mathrm{~d}$ & $0.402 \mathrm{~b}$ & $0.062 \mathrm{ab}$ & $0.937 \mathrm{a}$ \\
G1I1 & $3.942 \mathrm{c}$ & $743.465 \mathrm{c}$ & $0.763 \mathrm{~d}$ & $1.131 \mathrm{a}$ & $0.296 \mathrm{bc}$ & $0.021 \mathrm{~b}$ & $0.805 \mathrm{ab}$ \\
G2I1 & $1.643 \mathrm{f}$ & $713.878 \mathrm{~d}$ & $0.76 \mathrm{~d}$ & $0.411 \mathrm{c}$ & $1.238 \mathrm{a}$ & $0.055 \mathrm{ab}$ & $0.754 \mathrm{abc}$ \\
P1G1 & $3.041 \mathrm{e}$ & $1010.467 \mathrm{a}$ & $0.96 \mathrm{c}$ & $0.223 \mathrm{~d}$ & $0.279 \mathrm{bc}$ & $0.143 \mathrm{ab}$ & $0.66 \mathrm{bc}$ \\
P2G1 & $3.502 \mathrm{~d}$ & $655.986 \mathrm{f}$ & $1.262 \mathrm{~b}$ & $1.113 \mathrm{a}$ & $0.209 \mathrm{c}$ & $0.233 \mathrm{a}$ & $0.403 \mathrm{e}$ \\
CNS & $5.566 \mathrm{a}$ & $598.858 \mathrm{~g}$ & $0.883 \mathrm{~cd}$ & $0.516 \mathrm{c}$ & $0.178 \mathrm{c}$ & $0.115 \mathrm{ab}$ & $0.335 \mathrm{e}$ \\
CLCS & $3.597 \mathrm{~d}$ & $751.638 \mathrm{~b}$ & $1.488 \mathrm{a}$ & $0.57 \mathrm{bc}$ & $0.241 \mathrm{bc}$ & $0.052 \mathrm{ab}$ & $0.461 \mathrm{de}$ \\
\hline
\end{tabular}

Note: $\mathrm{C}=$ Compost, $\mathrm{P}=$ Proline; $\mathrm{G}=$ Gibberellic acid; $\mathrm{I}=$ Indole acetic acid; $\mathrm{CNS}=$ Control uncontaminated soil; $\mathrm{CLCS}=\mathrm{Control}$ contaminated soil, $1=$ Concentration at $5 \mathrm{mM}$ and rate at $20 \mathrm{tha}^{-1}, 2=$ Concentration at $10 \mathrm{mM}$ and rate at $40 \mathrm{t} \mathrm{ha}^{-1}$.

Table 3. Effect of combined application of different concentrations of proline and higher rate of hormones on photosynthetic pigments, stress indexes $\left(\mathrm{H}_{2} \mathrm{O}_{2}\right.$ and MDA), phenolics, proline and glycine betaine contents of maize.

\begin{tabular}{llllllll}
\hline Treatments & CHL & CRD & GB & PHNL & PROLINE & MDA & $\mathbf{H}_{2} \mathbf{O}_{2}$ \\
\hline P1I2 & $5.126 \mathrm{c}$ & $636.116 \mathrm{e}$ & $0.945 \mathrm{bcd}$ & $0.326 \mathrm{c}$ & $0.254 \mathrm{ab}$ & $0.025 \mathrm{~b}$ & $0.697 \mathrm{ab}$ \\
P2I2 & $4.569 \mathrm{~d}$ & $701.892 \mathrm{~d}$ & $0.834 \mathrm{~d}$ & $0.819 \mathrm{a}$ & $0.248 \mathrm{ab}$ & $0.038 \mathrm{~b}$ & $0.654 \mathrm{abc}$ \\
G1I2 & $6.786 \mathrm{a}$ & $137.968 \mathrm{~h}$ & $0.987 \mathrm{bcd}$ & $1.002 \mathrm{a}$ & $0.304 \mathrm{ab}$ & $0.015 \mathrm{~b}$ & $0.621 \mathrm{abcd}$ \\
G2I2 & $3.39 \mathrm{~g}$ & $527.505 \mathrm{~g}$ & $0.941 \mathrm{bcd}$ & $0.231 \mathrm{c}$ & $0.199 \mathrm{~b}$ & $0.012 \mathrm{~b}$ & $0.782 \mathrm{a}$ \\
P1G2 & $4.305 \mathrm{e}$ & $708.084 \mathrm{c}$ & $1.122 \mathrm{~b}$ & $0.21 \mathrm{c}$ & $0.157 \mathrm{~b}$ & $0.738 \mathrm{a}$ & $0.504 \mathrm{cde}$ \\
P2G2 & $4.241 \mathrm{e}$ & $769.71 \mathrm{a}$ & $1.026 \mathrm{bc}$ & $0.341 \mathrm{c}$ & $0.431 \mathrm{a}$ & $0.811 \mathrm{a}$ & $0.528 \mathrm{bcd}$ \\
CNS & $5.566 \mathrm{~b}$ & $598.858 \mathrm{f}$ & $0.883 \mathrm{~cd}$ & $0.516 \mathrm{~b}$ & $0.178 \mathrm{~b}$ & $0.115 \mathrm{~b}$ & $0.335 \mathrm{e}$ \\
CLCS & $3.597 \mathrm{f}$ & $751.638 \mathrm{~b}$ & $1.488 \mathrm{a}$ & $0.57 \mathrm{~b}$ & $0.241 \mathrm{~b}$ & $0.052 \mathrm{~b}$ & $0.461 \mathrm{de}$ \\
\hline
\end{tabular}

Note: $\mathrm{C}=$ Compost, $\mathrm{P}=$ Proline; $\mathrm{G}=$ Gibberellic acid; $\mathrm{I}=$ Indole acetic acid; $\mathrm{CNS}=$ Control uncontaminated soil; $\mathrm{CLCS}=$

Control contaminated soil, $1=$ Concentration at $5 \mathrm{mM}$ and rate at $20 \mathrm{t} \mathrm{ha}^{-1}, 2=$ Concentration at $10 \mathrm{mM}$ and rate at $40 \mathrm{t} \mathrm{ha}^{-1}$.

On the interactions between hormones in combination with proline, though the highest value of chlorophyll was recorded in uncontaminated control maize, but among the pretreated seeds, P1+I1 gave the highest value followed by maize pre-treated with G1+I1. Lowest chlorophyll content was recorded in maize pre-treated with G2+I1. For carotenoid, highest value was recorded in maize pre-treated with $\mathrm{P} 1+\mathrm{G} 1$ while, maize pre-treated with $\mathrm{P} 1+\mathrm{I} 1$ had the lowest. On the GB content, maize planted on contaminated soil had the highest value followed by those pre-treated with $\mathrm{P} 2+\mathrm{G} 1$ and the lowest value in maize pre-treated with G1+I1. On proline content seed pre-treated with G2+I1 had the highest value and lowest value of proline was found in maize grown on uncontaminated soil. Similarly, highest value of phenolics was recorded in maize pre-treated with $\mathrm{G} 1+\mathrm{I} 1$ followed by that of $\mathrm{P} 2+\mathrm{G} 1$ and those pre-treated with $\mathrm{P} 1+\mathrm{I} 1$. For hydrogen peroxide content, compared to control, seed pre-treatment with $\mathrm{P} 2+\mathrm{I} 1$ conversely gave the highest value followed by those pre-treated with G1+I1, while lowest hydrogen peroxide value was recorded in those grown on uncontaminated soil as well as maize pre-treated with $\mathrm{P} 1+\mathrm{G} 1$. Combined $\mathrm{P} 2+\mathrm{G} 1$ gave the highest malonyaldehyde (MDA) value followed by $\mathrm{P} 1+\mathrm{G} 1$ treatment. The lowest MDA value was recorded in maize pre-treated with G1+I1 followed by that of uncontaminated control (Table 2). The higher concentration of indole-acetic acid in combination with $\mathrm{G}$ and $\mathrm{P}$ gave different results compared to a lower rate. The result showed that the highest chlorophyll value was recorded in maize pre-treated with G1+I2 followed by maize grown on uncontaminated soil while lowest chlorophyll value was found in maize pre-treated with $\mathrm{G} 2+\mathrm{I} 2$. For carotenoid content, highest value was found in maize pre-treated with $\mathrm{P} 2+\mathrm{G} 2$, followed by maize grown on contaminated soil and those pre-treated with $\mathrm{P} 1+\mathrm{G} 2$. The lowest mean value was recorded in maize pre-treated with G1+I2. Except in maize grown on contaminated soil, GB was reduced in other 
treatments and the lowest value was recorded in maize pre-treated with higher concentration of proline combined with higher concentration of indole-acetic acid. On the proline content, maize pre-treated with $\mathrm{P} 2+\mathrm{G} 2$ had the highest value, followed by those pre-treated with G1+I2 and of contaminated control. However, the lowest proline value was recorded in maize pre-treated with $\mathrm{P} 1+\mathrm{G} 2$. The phenolic content of $\mathrm{Pb}$ stressed maize plant was found to increase when seeds were pre-treated with $\mathrm{G} 1+\mathrm{I} 2$ compared to that of untreated maize grown on contaminated soil. This was followed by the treatment with $\mathrm{P} 2+\mathrm{I} 2$. The lowest value was recorded in maize pre-treated with $\mathrm{P} 1+\mathrm{G} 2$ and maize pre-treated with $\mathrm{G} 2+\mathrm{I} 2$. On the stress indexes, more of hydrogen peroxide was produced in maize pre-treated with $\mathrm{I} 2$ in combination with $\mathrm{G}$ and $\mathrm{P}$ (i.e $\mathrm{G} 1+\mathrm{I} 2, \mathrm{G} 2+\mathrm{I} 2, \mathrm{P} 1+\mathrm{I} 2$ and $\mathrm{P} 2+\mathrm{I} 2$ ) compared to control. Lowest value was recorded in maize grown on uncontaminated soil. Similarly, MDA content was more in maize pre-treated with lower concentration of proline and gibberellin when combined with higher concentration of indole-acetic acid while reduced values were recorded in other treatments including control (Table 3).

\section{Photosynthetic pigments, proline, glycine betaine, phenolics and stress indexes $\left(\mathrm{H}_{2} \mathrm{O}_{2}\right.$ and MDA) of maize grown on $P b$ contaminated soil as affected by combined application of proline, hormone and compost}

Using lower rate of compost, highest value of chlorophyll was recorded in maize pre-treated with $\mathrm{G} 2+\mathrm{C} 1$. This was followed by maize pre-treated with $\mathrm{I} 2+\mathrm{C} 1$ and maize grown on uncontaminated soil. The lowest value of chlorophyll was found in maize pre-treated with $\mathrm{I} 1+\mathrm{C} 1$. However, maize pre-treated with $\mathrm{I} 1+\mathrm{C} 1$ had the highest carotenoid value followed by those pre-treated with $\mathrm{P} 1+\mathrm{C} 1$ and $\mathrm{P} 2+\mathrm{C} 1$. The lowest value was recorded in maize pre-treated with $\mathrm{G} 2+\mathrm{C} 1$. Compared to control, maize pre-treatment with proline in combination with $\mathrm{C} 1$ had no significant effect on chlorophyll content. As observed above, GB was more in untreated maize planted on contaminated soil without amendment. This was followed by that of maize plant pre-treated with $\mathrm{P} 1+\mathrm{C} 1$ and those pre-treated with $\mathrm{G} 2+\mathrm{C} 1$. The lowest value was recorded in maize pre-treated with $\mathrm{G} 1+\mathrm{C} 1$ and maize pre-treated with $\mathrm{I} 2+\mathrm{C} 1$. Among the combinations, for the leaf proline content, the highest value was recorded in maize pre-treated with $\mathrm{P} 1+\mathrm{C} 1$ followed by maize pre-treated with $\mathrm{G} 2+\mathrm{C} 1$ while, the lowest value was recorded in maize grown on uncontaminated soil. Phenolic content was more in maize treated with $\mathrm{G} 1+\mathrm{C} 1$ followed by $\mathrm{I} 1+\mathrm{C} 1$ and $\mathrm{I} 2+\mathrm{C} 1$. Compared to other treatments, maize pre-treatment with the combination of proline at both rates with a lower rate of compost, however, reduced the phenolic content in maize. On stress indexes of maize, hydrogen peroxide, was more in maize pre-treated with $\mathrm{P} 2+\mathrm{C} 1$ followed by those pre-treated with $\mathrm{P} 1+\mathrm{C} 1$. Lowest hydrogen peroxide content was recorded in maize pre-treated with $\mathrm{G} 2+\mathrm{C} 1$. Meanwhile, malonylaldehyde (MDA) content was recorded to be the highest in maize pre-treated with $\mathrm{I} 1+\mathrm{C} 1$ followed by maize pre-treated with $\mathrm{P} 2+\mathrm{C} 1$. The lowest value was found in $\mathrm{G} 1+\mathrm{C} 1$ and $\mathrm{G} 2+\mathrm{C} 1$ and not significantly different from those grown on contaminated and uncontaminated soil (Table 4).

Table 4. Effect of combined application of different concentrations of proline, hormones and lower rate of compost on photosynthetic pigments, stress indexes $\left(\mathrm{H}_{2} \mathrm{O}_{2}\right.$ and MDA), phenolics (PHNL), proline and glycine betaine (GB) contents of maize.

\begin{tabular}{llllllll}
\hline Treatments & CHL & CRD & GB & PHNL & PROLINE & MDA & $\mathbf{H}_{2} \mathbf{O}_{2}$ \\
\hline P1C1 & $3.626 \mathrm{e}$ & $781.226 \mathrm{~b}$ & $1.249 \mathrm{~b}$ & $0.416 \mathrm{bc}$ & $0.371 \mathrm{a}$ & $0.167 \mathrm{~cd}$ & $0.588 \mathrm{ab}$ \\
P2C1 & $3.659 \mathrm{e}$ & $762.436 \mathrm{c}$ & $0.828 \mathrm{~cd}$ & $0.331 \mathrm{c}$ & $0.209 \mathrm{ab}$ & $0.371 \mathrm{~b}$ & $0.71 \mathrm{a}$ \\
G1C1 & $4.824 \mathrm{~d}$ & $652.681 \mathrm{e}$ & $0.694 \mathrm{~d}$ & $0.903 \mathrm{a}$ & $0.241 \mathrm{ab}$ & $0.569 \mathrm{a}$ & $0.485 \mathrm{bc}$ \\
G2C1 & $7.79 \mathrm{a}$ & $302.498 \mathrm{~h}$ & $1.14 \mathrm{~b}$ & $0.516 \mathrm{~b}$ & $0.349 \mathrm{ab}$ & $0.27 \mathrm{bc}$ & $0.232 \mathrm{e}$ \\
I1C1 & $2.914 \mathrm{f}$ & $816.344 \mathrm{a}$ & $0.914 \mathrm{c}$ & $0.825 \mathrm{a}$ & $0.23 \mathrm{ab}$ & $0.022 \mathrm{~d}$ & $0.291 \mathrm{de}$ \\
I2C1 & $5.881 \mathrm{~b}$ & $591.947 \mathrm{~g}$ & $0.711 \mathrm{~d}$ & $0.794 \mathrm{a}$ & $0.251 \mathrm{ab}$ & $0.027 \mathrm{~d}$ & $0.448 \mathrm{bcd}$ \\
CNS & $5.566 \mathrm{c}$ & $598.858 \mathrm{f}$ & $0.883 \mathrm{c}$ & $0.516 \mathrm{~b}$ & $0.178 \mathrm{~b}$ & $0.115 \mathrm{~cd}$ & $0.335 \mathrm{cde}$ \\
CLCS & $3.597 \mathrm{e}$ & $751.638 \mathrm{~d}$ & $1.488 \mathrm{a}$ & $0.57 \mathrm{~b}$ & $0.241 \mathrm{ab}$ & $0.052 \mathrm{~d}$ & $0.461 \mathrm{bcd}$ \\
\hline
\end{tabular}

Note: $\mathrm{C}=$ Compost; $\mathrm{P}=$ Proline; $\mathrm{G}=$ Gibberellic acid; $\mathrm{I}=$ Indole acetic acid; $\mathrm{CNS}=$ Control uncontaminated soil; $\mathrm{CLCS}=$ Control contaminated soil; $1=$ Concentration at $5 \mathrm{mM}$ and rate at $20 \mathrm{t} \mathrm{ha}^{-1} ; 2=$ Concentration at $10 \mathrm{mM}$ and rate at $40 \mathrm{t} \mathrm{ha}^{-1}$; $\mathrm{CRD}=$ Carotenoids; $\mathrm{CHL}=$ Chlorophyll.

Amendment of contaminated soil with higher compost rate (C2), gave a remarkable increase in the chlorophyll content of maize pre-treated with P2 and P1 while the lowest was recorded in maize pre-treated with I2. However, the highest value of carotenoid was recorded in maize pre-treated with G2 and G1 but the lowest value was found in maize pre-treated with P2. A combination of higher rate of compost and seed pretreatment with exogenous proline and hormone also reduced the glycine betaine production in stressed maize compared to contaminated control and were not significantly different from those grown on uncontaminated soil. The highest value was recorded in maize grown on contaminated soil. For proline content, the highest value was found in maize pre-treated with indole-acetic acid. Meanwhile, seed pretreatment with proline in combination with higher rate of compost reduced the amount of endogenous proline and lowest value was recorded in maize pre-treated with higher concentration of proline combined with higher rate of compost. For the phenolic content of maize, the highest value was recorded in maize pre-treated with $\mathrm{G} 1+\mathrm{C} 2$ and lowest in maize pre-treated with $\mathrm{G} 2+\mathrm{C} 2$ followed by that of $\mathrm{P} 2+\mathrm{C} 2$. Hydrogen peroxide content was 
recorded to be the highest in maize pre-treated with $\mathrm{I} 2$ in combination with $\mathrm{C} 2$. Lowest value was recorded in those pretreated with G2 and grown on soil amended with C2. Similarly, the lowest MDA value was recorded in maize pretreated with G1 while the highest was in maize pre-treated with I1. This was followed by maize pre-treated with P2 and combined with higher rate of compost (Table 5).

Table 5. Effect of combined application of different concentrations of proline, hormones and higher rate of compost on photosynthetic pigments, stress indexes $\left(\mathrm{H}_{2} \mathrm{O}_{2}\right.$ and MDA), phenolics, proline and glycine betaine contents of maize.

\begin{tabular}{llllllll} 
Treatments & CHL & CRD & GB & PHNL & PROLINE & MDA & H $_{2} \mathbf{O}_{2}$ \\
\hline P1C2 & $6.412 \mathrm{~b}$ & $490.17 \mathrm{~g}$ & $0.886 \mathrm{c}$ & $0.737 \mathrm{a}$ & $0.211 \mathrm{~b}$ & $0.035 \mathrm{~b}$ & $0.538 \mathrm{ab}$ \\
P2C2 & $8.286 \mathrm{a}$ & $(-) 341.123 \mathrm{~h}$ & $0.826 \mathrm{c}$ & $0.537 \mathrm{~b}$ & $0.156 \mathrm{~b}$ & $0.281 \mathrm{a}$ & $0.591 \mathrm{ab}$ \\
G1G2 & $3.902 \mathrm{e}$ & $811.697 \mathrm{~b}$ & $0.515 \mathrm{~d}$ & $0.914 \mathrm{a}$ & $0.276 \mathrm{~b}$ & $0.345 \mathrm{a}$ & $0.415 \mathrm{bc}$ \\
G2C2 & $2.638 \mathrm{~g}$ & $826.996 \mathrm{a}$ & $1.093 \mathrm{~b}$ & $0.331 \mathrm{c}$ & $0.262 \mathrm{~b}$ & $0.343 \mathrm{a}$ & $0.343 \mathrm{c}$ \\
I1C2 & $5.136 \mathrm{~d}$ & $525.359 \mathrm{f}$ & $0.853 \mathrm{c}$ & $0.847 \mathrm{a}$ & $0.664 \mathrm{a}$ & $0.012 \mathrm{~b}$ & $0.57 \mathrm{ab}$ \\
I2C2 & $2.358 \mathrm{~h}$ & $747.494 \mathrm{~d}$ & $0.598 \mathrm{~d}$ & $0.923 \mathrm{a}$ & $0.602 \mathrm{a}$ & $0.025 \mathrm{~b}$ & $0.625 \mathrm{a}$ \\
CNS & $5.566 \mathrm{c}$ & $598.858 \mathrm{e}$ & $0.883 \mathrm{c}$ & $0.516 \mathrm{~b}$ & $0.178 \mathrm{~b}$ & $0.115 \mathrm{~b}$ & $0.335 \mathrm{c}$ \\
CLCS & $3.597 \mathrm{f}$ & $751.638 \mathrm{c}$ & $1.488 \mathrm{a}$ & $0.57 \mathrm{~b}$ & $0.241 \mathrm{~b}$ & $0.052 \mathrm{~b}$ & $0.461 \mathrm{abc}$ \\
\hline
\end{tabular}

Note: $\mathrm{C}=$ Compost; $\mathrm{P}=$ Proline; $\mathrm{G}=$ Gibberellic acid; $\mathrm{I}=$ Indole acetic acid; $\mathrm{CNS}=$ Control uncontaminated soil; $\mathrm{CLCS}=$

Control contaminated soil; $1=$ Concentration at $5 \mathrm{mM}$ and rate at $20 \mathrm{tha}^{-1} ; 2=$ Concentration at $10 \mathrm{mM}$ and rate at $40 \mathrm{tha}^{-1}$.

Effect of sole and combined application of different concentrations of proline, hormones and compost on soil and plant lead (Pb) concentrations.

Contaminated soil without compost amendment had more post-cropping soil $\mathrm{Pb}$ concentration compared to unamended soil and the soil where proline treated seeds were planted had the highest. Apart from the uncontaminated soil, the lowest value was recorded in soil amended with 40t/ha compost (Fig. 1A). The same trend was observed under combined treatments, the post-cropping soil lead content was the highest in the unamended contaminated soil compared to amended soil. Unlike what was observed under sole application where treated seeds were sown on unamended soil, the soil $\mathrm{Pb}$ content was reduced in the soil that received compost and was sown with pretreated seeds (Fig. 1B). For example, under sole proline treatment (P2) without compost, the post-cropping soil $\mathrm{Pb}$ was $46854 \mathrm{mg} \mathrm{kg}^{-1} \mathrm{~Pb}$ but the value was reduced with soil amendment with 20 and $40 \mathrm{t} \mathrm{ha}^{-1}$ to 25108 and $10925 \mathrm{mg} \mathrm{kg}^{-1}$, respectively. Addition of higher rate of compost to $\mathrm{Pb}$ contaminated soil generally reduced post-cropping soil $\mathrm{Pb}$ compared to untreated contaminated soil except in P1C2 treatment (maize pre-treated with lower proline concentration) and grown on soil combined with higher compost rate (Fig. 1C). Apart from the uncontaminated soil, the lowest value for post-cropping $\mathrm{Pb}$ concentration was found in $\mathrm{P} 2 \mathrm{C} 2$ treatment.

Conversely, with regards to the $\mathrm{Pb}$ accumulation in the shoot and root, the untreated control plant grown on untreated contaminated soil had the lowest compared to the pretreated maize plant. On the effect of sole treatment, $\mathrm{Pb}$ accumulation in the shoot of maize was found to be the highest in the untreated maize seeds planted on contaminated soil amended with $\mathrm{C} 2$. This was followed by the concentration in the maize pre-treated with a higher concentration of indole acetic acid (Fig. 2A). The lowest mean value for lead in the shoot was recorded in maize pre-treated with gibberellic acid at $10 \mathrm{mM}$ and the control maize plants (Fig. 2B). Treatment with gibberrellic acid and higher compost rate also gave the lowest values though not significantly different from the contaminated control (Fig. 2C). The shoot lead content was however low in the two proline treatments compared to other treatments while the highest shoot lead content was recorded in maize pre-treated with $\mathrm{G} 1 \mathrm{C} 1$ followed by that of I1C1 followed by maize pre-treated with higher concentration of indole-acetic acid in combination with lower concentration of compost (Fig. 2C).

$\mathrm{Pb}$ concentration in the root was generally more than that of the shoot in most treatments. Sole treatments of $\mathrm{C} 1$ and P2 treatments increased the lead concentration in the root while the lowest was recorded for G2 treatment (Fig. 3A). Seed pre-treated with a lower and higher concentration of proline and grown on soil amended with compost, however, had the highest mean value which were not significantly different from each other while the lowest mean value was found in maize pre-treated with lower gibberellic concentration combined with higher compost rate (Figs 3B, C).

\section{DISCUSSION}

Plant productivity depends on different environmental and endogenous factors which in turn control plant's behaviour and responses. These factors may act independently, additively, interactively or synergistically. The survival of crop therefore, depends on the complex interactions among the various environmental factors and processes taking place within the plant. In this study, sole and combined application of different concentrations of proline, hormones and compost induced different physiological and biochemical responses in maize crop grown on $\mathrm{Pb}$ contaminated soil. The response was found to depend on the type of treatment and concentrations. A combination of these treatments was more 

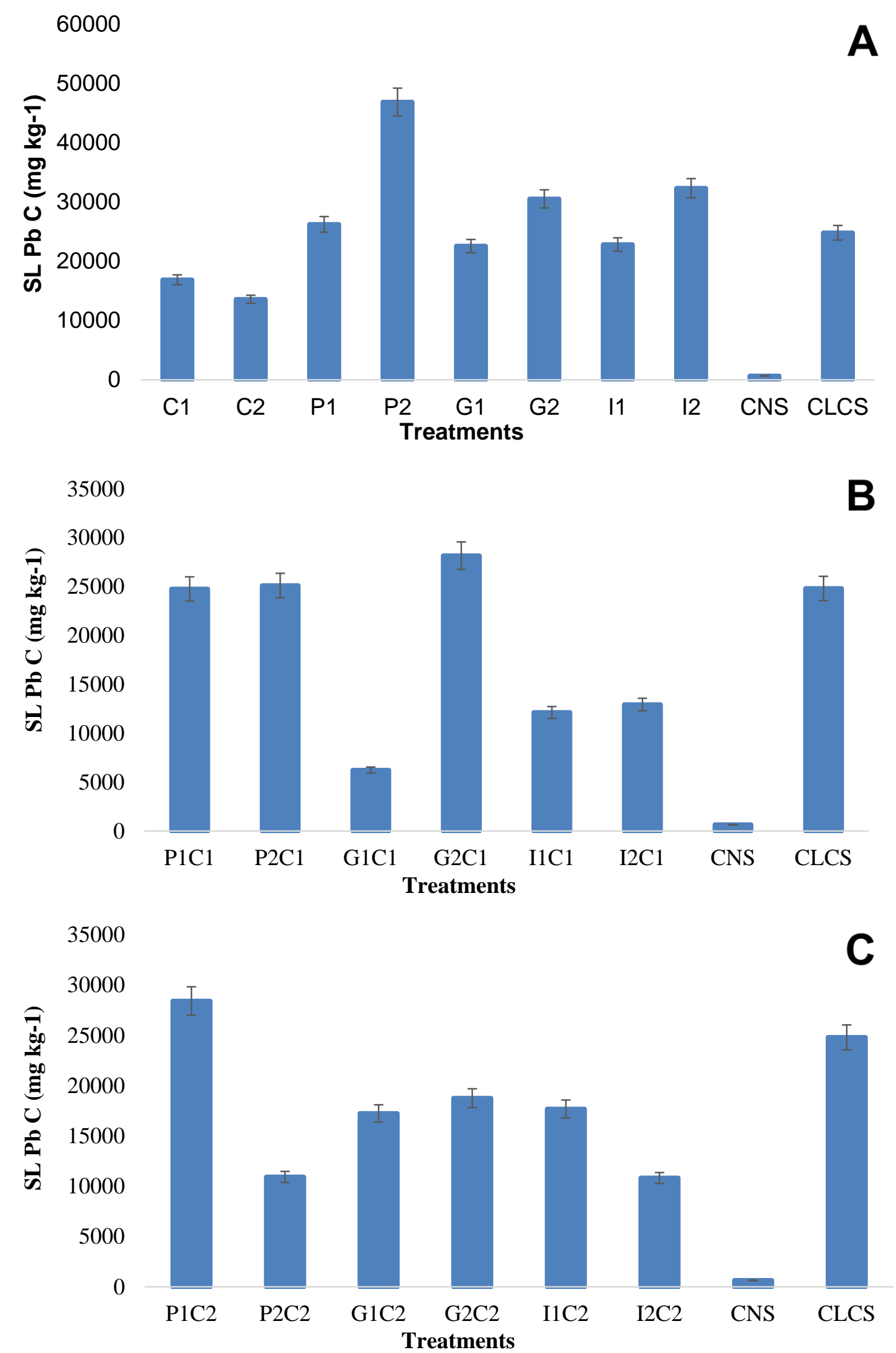

Figure 1. Effect of sole and combined application of different concentrations of proline, hormones and compost on post cropping soil lead contents (Bars on chart represent standard error).

[Note: Chart $\mathrm{A}=$ Sole effect of treatments on soil $\mathrm{Pb}$ concentration, Chart $\mathrm{B}=$ Interactive effect of Proline and hormones with lower rate of compost, Chart $\mathrm{C}=$ Interactive effect of Proline and hormones with higher rate of compost; $\mathrm{C}=\mathrm{Compost}$; $=\mathrm{Proline}$; $\mathrm{G}=$ Gibberellic acid; $\mathrm{I}=$ Indole acetic acid; $\mathrm{CNS}=\mathrm{Control}$ uncontaminated soil; $\mathrm{CLCS}=\mathrm{Control}$ contaminated soil: $1=\mathrm{Concentration}$ at 5 $\mathrm{mM}$ and compost rate at $20 \mathrm{tha}^{-1}, 2=$ Concentration at $10 \mathrm{mM}$ and compost rate at $40 \mathrm{t} \mathrm{ha}^{-1} ; \mathrm{S} \mathrm{Pb} \mathrm{C}=$ Soil lead content] 

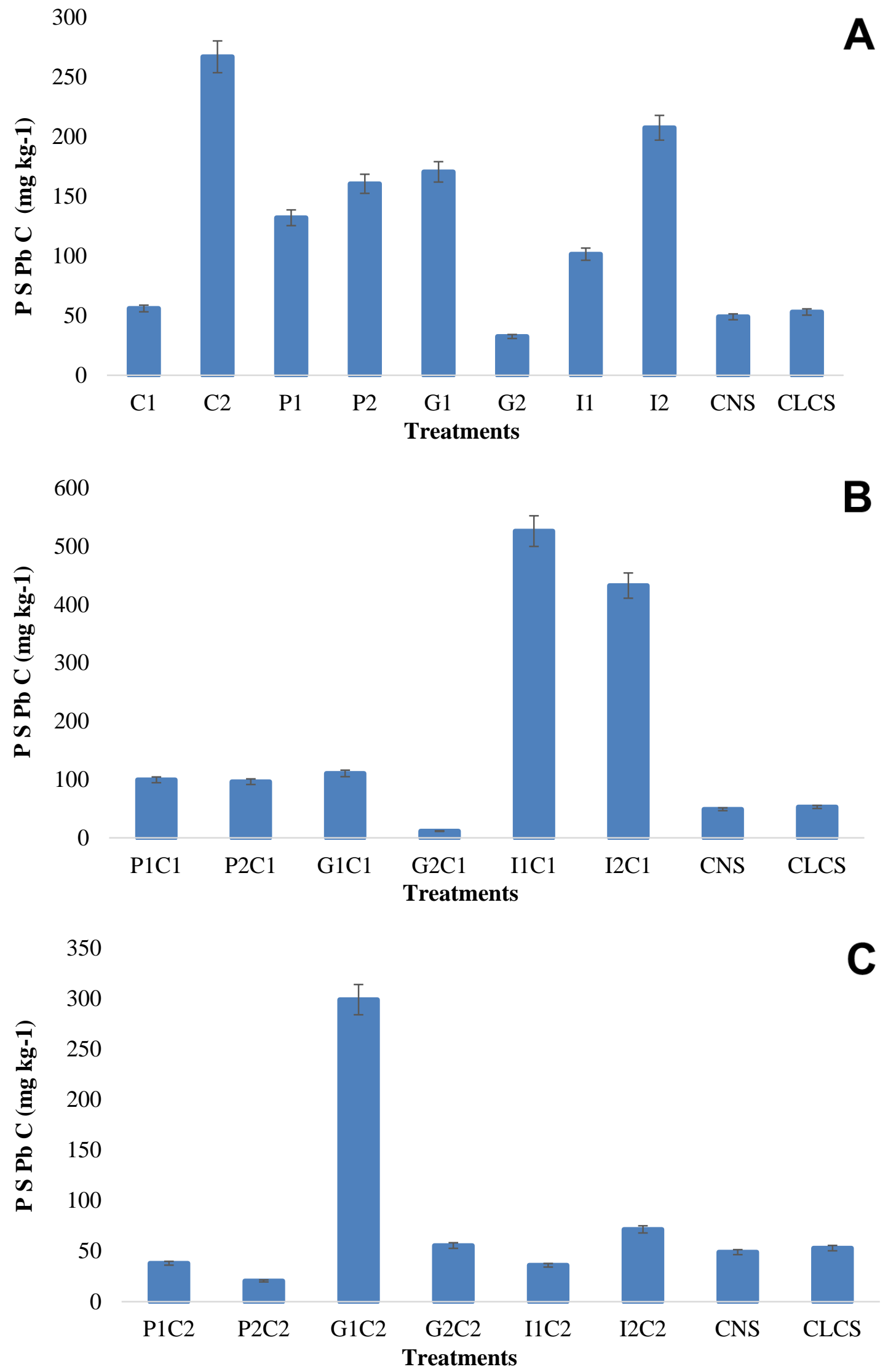

Figure 2. Effect of sole and combined application of different concentrations of proline, hormones and compost on shoot lead content of maize (Bars on chart represent standard error).

[Note: Chart $\mathrm{A}=$ Sole effect of treatments on shoot $\mathrm{Pb}$ concentration, Chart $\mathrm{B}=$ Interactive effect of Proline and hormones with lower rate of compost, Chart $\mathrm{C}=$ Interactive effect of Proline and hormones with higher rate of compost; $\mathrm{C}=\mathrm{Compost}$; $\mathrm{P}=\mathrm{Proline}$; $\mathrm{G}=$ Gibberellic acid; $\mathrm{I}=$ Indole acetic acid $\mathrm{CNS}=\mathrm{Control}$ uncontaminated soil; $\mathrm{CLCS}=\mathrm{Control}$ contaminated soil; $1=$ concentration at $5 \mathrm{mM}$ and compost rate at $20 \mathrm{tha}^{-1} ; 2=$ Concentration at $10 \mathrm{mM}$ and compost rate at $40 \mathrm{tha}^{-1} ; \mathrm{P} \mathrm{S} \mathrm{Pb} \mathrm{C}=$ plant shoot lead content. 


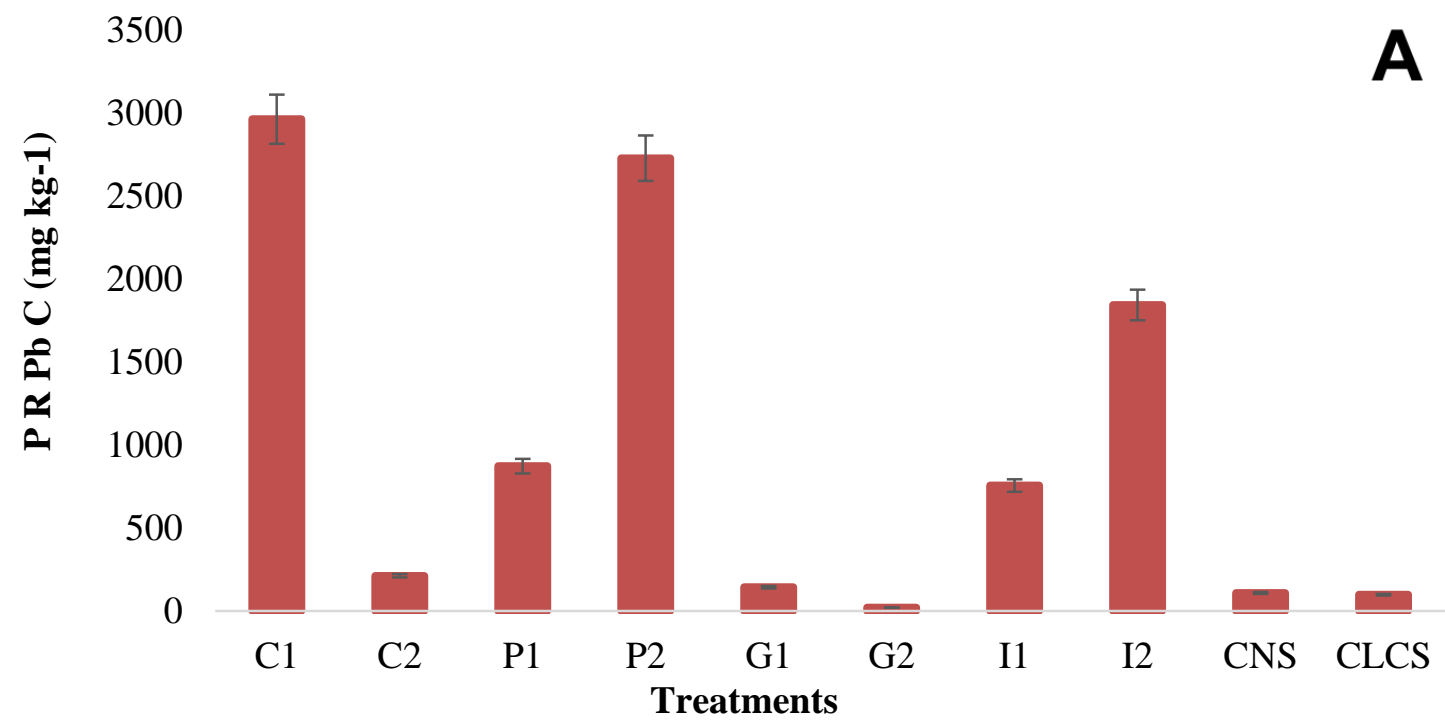

1600

B
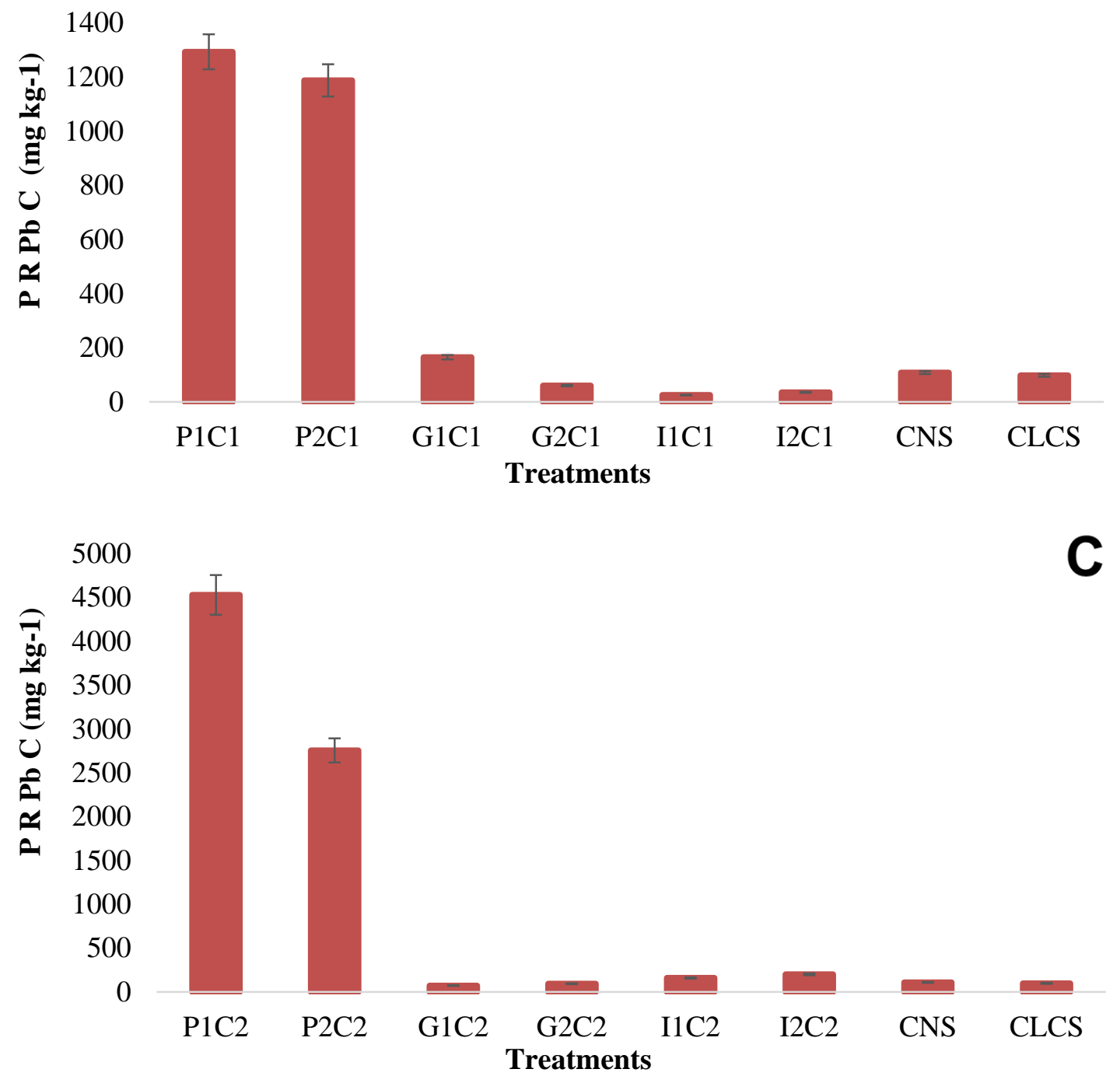

Figure 3. Effect of sole and combined application of different concentrations of proline, hormones and compost on root lead content of maize (Bars on chart represent standard error).

[Note: Chart $\mathrm{A}=$ Sole effect of treatments on Root $\mathrm{Pb}$ concentration, Chart $\mathrm{B}=$ Interactive effect of Proline and hormones with lower rate of compost, Chart $\mathrm{C}=$ Interactive effect of Proline and hormones with higher rate of compost; $\mathrm{C}=\mathrm{Compost}, \mathrm{P}=\mathrm{Proline}$, $\mathrm{G}=$ Gibberellic acid; $\mathrm{I}=$ Indole acetic acid $\mathrm{CNS}=\mathrm{Control}$ uncontaminated soil; $\mathrm{CLCS}=\mathrm{Control}$ contaminated soil; $1=\mathrm{Concentration}$ at $5 \mathrm{mM}$ and rate at $20 \mathrm{t} \mathrm{ha}^{-1} ; 2=$ Concentration at $10 \mathrm{mM}$ and rate at $40 \mathrm{t} \mathrm{ha}^{-1} ; \mathrm{P} \mathrm{R} \mathrm{Pb} \mathrm{C}=$ Plant root lead content] 
effective and synergistically enhanced maize growth and survival on contaminated soil more than sole treatments. This was reflected in the different parameters considered. For instance, chlorophyll production and osmolytes accumulation were found to be more in the combined treatments of proline, hormones and compost compared to sole treatments. These might be attributed to the interactions between these treatments with one compensating for the lapses of the other or causing each other to become more active. Hormones have been reported to have an interplay among themselves that usually results in better performance when used at the appropriate concentration (Mayank et al., 2015). Similarly, lower concentration of hormones was also found to perform better than higher concentration since hormones have been known to be required in minute concentration.

High concentration of heavy metals disrupt the metabolic activities in plant due to increase in the production of reactive oxygen species (ROS) such as superoxide radicals, hydroxyl radicals, and hydrogen peroxide $\left(\mathrm{H}_{2} \mathrm{O}_{2}\right)\left(\mathrm{Verma}_{\mathrm{C}}\right.$ Dubey, 2003; Souguir et al. 2011). ROS can cause oxidative damage to the biomolecules when produced in larger amounts leading to cell membrane peroxidation, loss of ions, protein hydrolysis, and even DNA strand breakage (Cakmak \& Horst, 1991; Hossain et al., 2012). Plants have developed enzymatic and non-enzymatic anti-oxidative system to scavenge the ROS. Carotenoid, Glycine betaine and proline are examples of compatible osmolytes known to induce abiotic stress tolerance in plants (Sakamoto \& Murata, 2002; Claussen, 2005). Exogenous supply of proline in this study was found to induce stress tolerance in heavy metal stressed maize plants. This observation confirms the assertion that proline is capable of inducing stress tolerance in crops (Islam et al., 2009; Adejumo et al., 2015; Noreen et al., 2018). The effect of treatments was also reflected in the endogenous concentration of the stress-related metabolites in the treated and untreated maize plants grown on contaminated soil.

For example, carotenoids unlike chlorophyll, has been identified as one of the non-enzymatic mechanisms of stress responsiveness in plant (Hossain et al., 2012). All the seeds pretreated with sole application of proline and in combination with soil amendment with a higher rate of compost had reduced concentration of carotenoids compared to the untreated seeds. A combination of gibberellin with a lower rate of IAA and compost also reduced the carotenoid content. This high carotenoid concentration in the untreated maize (control) grown on unamended $\mathrm{Pb}$ contaminated soil agrees with the report of Adejumo et al. (2018c) that carotenoid production was enhanced in the plant exposed to drought stress than the unstressed plant. However, the reduction in carotenoid concentration in the pretreated plants might be connected with the stress amelioration as a result of maize pretreatment with proline and organic amendments. Compost amendments has also been reported to confer tolerance on crop grown on contaminated soils by making nutrients available for crop (Adejumo et al. 2011). Similar to what was observed for carotenoid, production of glycine betaine which is another stress related metabolite (Prasad \& Saradhi, 2004; Chen \& Murata, 2011), was also reduced in response to seed pretreatment with proline and hormone as well as soil amendment with compost. Glycine betaine content was high in maize planted on contaminated soil without seed pretreatment or soil amendment. This therefore implies that seed pretreatment with proline and hormones coupled with soil augmentation with compost was able to reduce the heavy metal stress in maize crop. Tolerance to extreme osmotic stress and drought has been reported to be due to the production of plant metabolites like glycine betaine, proline and trehalose as compatible solutes (osmoprotectants) (Nyyssölä \& Leisola, 2001; Sakamoto \& Murata, 2002; Adejumo et al. 2018a). Accumulation of Glycine betaine and phenolics have also been found to play a major role in the tolerance mechanism under stress in higher plants (Takahama \& Oniki, 2000; Shen et al., 2002; Ashraf \& Foolad, 2007). Glycine betaine protects the photosynthetic apparatus under stress conditions by stabilizing the PSII complex (Banu et al., 2009; Adams et al., 2013). In all, combined treatments was more effective in terms of stress amelioration and GB production compared to sole treatment.

The production of proline which is another stress tolerance amino acid was also affected by the seed pretreatments with proline and hormone and soil amendment with compost. Probably, due to stress reduction, the lowest proline value was recorded in maize pre-treated with a higher concentration of proline and combined with a higher rate of compost. Combined treatments, however, reduced the proline level more than the sole treatments compared to control plant due to enhanced reduction in stress. This could have been responsible for the survival of maize plant on contaminated soil up to 10 weeks after sowing compared to the untreated maize on contaminated soil. Meanwhile, as observed by Noreen et al. (2018) that exogenous application of proline enhanced proline production in wheat, seed pretreatments with sole proline induced endogenous production of proline more than other treatments but by combining the treatments, the concentration of proline was reduced, though, this was rate dependent. Proline treatment at any rate in combination with a higher rate of compost was more effective in reducing proline concentration as observed for GB. The reduction in the concentration of these metabolites in the pre-treated maize plants and compost amendment treatments could be attributed to stress amelioration in the metal stressed maize and reduced synthesis under stress conditions (Kavi Kishor et al., 2005). Exogenous supply of proline to osmotically stressed callus of rice also increased the growth of callus in 
vitro by increasing the stress tolerance. This is because these metabolites especially, proline seem to have diverse roles under osmotic stress conditions, such as stabilization of proteins, membranes and subcellular structures and protecting cellular functions by scavenging reactive oxygen species (Vanrensburg et al., 1993; Kavi Kishor et al., 2005). Stressinduced oxygenase activity of Rubisco is also said to be suppressed by proline thereby protecting photosynthetic activity under stress while its activity is enhanced as a result of glycine betaine accumulation in the chloroplast during stress (Zhang et al., 1997; Prasad \& Saradhi, 2004). Sole application of lower rate of proline for seed soaking and in combination with hormones also reduced the phenolic content in maize leaf compared to other treatments. This indicates that proline transporters exist in plants that probably transport the exogenous proline in and within the treated plant thereby inducing the tolerance in plant.

It is noteworthy that, indole-acetic acid behaved as stress inducer in plants when compared to proline and gibberellic acid treatments. Indole acetic acid rather than ameliorating the stress effect in maize, it reduced germination and growth of maize on contaminated soil in our previous study (Awoyemi \& Adejumo, 2018). The negative effect of this hormone was also reflected on the stress indexes under this study. Hydrogen peroxide and malonylaldehyde which are stress indexes were more in plants pre-treated with higher and lower concentrations ( $5 \mathrm{mM}$ and $10 \mathrm{mM})$ of indole-acetic acid as well as in combination with proline and gibberellin which signifies an increase in stress (Hossain et al. 2011). This agrees with the finding of Sarvesh et al. (1966) that plant growth regulators such as indole-3-butyric acid (IBA), kinetin but not gibberellic acid (GA) initiated proline accumulation in seedlings of Guizotia abyssinica whereas, NaCl-induced growth inhibition was alleviated by an exogenous supply of GA and ABA, but not by IBA and kinetin in seedlings of Niger as was also observed in this study. However, compared to sole application, combining other treatments with IAA enhanced tolerance in maize and reduced the stress indexes and GB concentration possibly due to interactions among the different treatments but maize pre-treated with a lower concentration of gibberellic acid and combined with indoleacetic acid and compost increased the maize phenolic and proline contents. Seed pretreatment with IAA and sown on soil amended with high rate of compost increased proline concentration in maize leaf more than other treatments. Sole treatment with indole acetic acid unlike other treatments also increased the GB concentration in maize leaf. This can be related to the induced increase in the activity of enzymes involved in the synthesis of these compounds under heavy metal stress (Lattanzio et al. 2006).

Conversely, it was recorded that post cropping soil $\mathrm{Pb}$ was more in the soil-grown with the seeds pretreated with sole application of proline at $10 \mathrm{mM}$ and was more than that of control. Therefore, survival of maize plant on this soil must have been really assisted with the seed pretreatment with exogenous proline. The addition of compost to the contaminated soil however, reduced the soil $\mathrm{Pb}$ concentration compared to the soil without amendment but with the seed treated with proline and hormone only. This observation agrees with the findings of the previous researchers on the ability of compost to increase soil nutrients and reduce heavy metal concentrations in the soil. Composts have been able to improve soil fertility and quality because of the increase in organic matter content which has been reported to have greater affinity for heavy metals (Rennevan et al., 2007; Fleming et al., 2013). Apart from increasing soil organic matter content, composts improve soil physical properties such as structural stability, total porosity and hydraulic conductivity (Tejada et al., 2009). Meanwhile, soil amendment with higher concentration of compost increased $\mathrm{Pb}$ translocation to shoot more than other treatments as observed in the previous findings where $\mathrm{Pb}$ was found to be more in the maize grown on soil amended with higher compost rate (Adejumo et al., 2010). The uptake of any element by plant, either toxic or non-toxic is said to be biomass dependent. This could have also explained the lower Pb content recorded for contaminated control plant that had the lowest plant biomass. Besides, crop response to environmental stresses like heavy metal contamination at molecular, cellular and physiological levels is very complex. It is not surprising that the maize response to heavy metal contamination is a complex process in plants. This is because, presence of a toxic element in the growing medium will influence the selective absorption/uptake of essential elements in the soil as well as disrupt the metabolic processes that make use of these nutrients all of which will results in yield reduction as observed in the control plant grown on contaminated soil alone. This again might have led to the disruption in the normal physiological processes which in turn could have also resulted in the accumulation of the toxic metal in the plant at the expense of the essential mineral nutrients. Stress tolerance and resistance are said to be controlled at the transcriptional level by an extremely intricate gene regulatory network (Chen et al. 2002, 2004). The effective strategies for ensuring crop production in the face of soil contamination challenges are said to be immobilization in the soil, restriction to the root and tolerance enhancement. Plants' defenses to metal toxicity may also constitute avoidance of metal entry into the cell through the exclusion principle or binding of metal to the cell wall. The binding to cell wall has been described as a major detoxification mechanism of preventing the toxic metals from entering into the cell and damaging the sensitive organelles (Antosiewicz \& Wierzbicka, 1999). 


\section{CONCLUSION AND RECOMMENDATION}

This study showed that pre-treatment of seeds with a higher concentration of proline $(10 \mathrm{mM})$ and application of higher rate of compost $\left(40 \mathrm{t} \mathrm{ha}^{-1}\right)$ on the soil resulted in greater performance. Lowest proline value was recorded in maize pre-treated with a higher concentration of proline combined with higher rate of compost. Combination of higher rate of compost and seed pretreatment with exogenous proline and hormone also reduced glycine betaine production in stressed maize compared to contaminated control. Soil amendment with compost and seed pretreatment with proline and hormone either as sole treatment or in combination however reduced the shoot $\mathrm{Pb}$ concentration by decreasing the translocation to the shoot and retaining it in the root. The use of high concentration of proline combined with higher rate of compost should, therefore, be encouraged and implemented when growing plants on contaminated or degraded soil so as to increase crop yield and reduce the effect of $\mathrm{Pb}$ on maize crop. Seed pretreatments with sole proline, gibberellin $(5 \mathrm{mM})$, IAA $(10 \mathrm{mM})$ and compost $\left(20 \mathrm{t} \mathrm{ha}^{-1}\right)$ induced endogenous production of proline more than control.

\section{ACKNOWLEDGEMENTS}

The authors are thankful to Department of Crop Protection and Environmental Biology, Faculty of Agriculture, University of Ibadan, Ibadan, Nigeria for providing required facilities and supports during the study.

\section{REFERENCES}

Adams W.W., Muller O., Cohu C.M. \& Demmig-Adams B. (2013). May photoinhibition be a consequence, rather than a cause, of limited plant productivity? Photosynthesis Research, 117: 31-44.

Adejumo S.A., Togun A.O., Adediran J.A. \& Ogundiran M.B. (2010). Effects of compost application on remediation and the growth of maize planted on lead contaminated soil. In: Proceedings of the $19^{\text {th }}$ World Congress of Soil Science, Soil Solutions for a Changing World. 1-6 August 2010, Brisbane, Australia, pp. 99-102.

Adejumo S.A., Togun A.O., Adediran J.A. \& Ogundiran M.B. (2011). Field assessment of progressive remediation of soil contaminated with lead-acid battery waste in response to compost application. Pedologist, 54(3): 182-193.

Adejumo S.A., Awodoyin R.O. \& Togun A.O. (2012). Re-establishment of vegetation on soil contaminated by heavy metals in response to Mexican sunflower and cassava peels composts. Environtropica, 8: 120-131.

Adejumo S.A., Adeosun A.A., Olaniyan A.B. \& Awodoyin R.O. (2015). Seasonal variations in distribution, heavy metal uptake and proline production of native plants growing on $\mathrm{Pb}$ contaminated site in Ibadan South-Western, Nigeria. Nigerian Journal of Ecology, 14: 37-47.

Adejumo S.A., Ezeh O.S. \& Mur L.A.J. (2018a). Okra growth and drought tolerance when exposed to water regimes at different growth stages. International Journal of Vegetable Science, 25(3): 226-258.

Adejumo S.A., Tiwari S., Shinde V. \& Sarangi B.K. (2018b). Heavy metal (Pb) accumulation in metallophytes as influenced by the variations in rhizospheric and non-rhizospheric soils physico-chemical characteristics. International Journal of Phytoremediation, 20(3): 237-248.

Adejumo S.A., Ogundiran M.B. \& Togun A.O. (2018c). Soil amendment with compost and crop growth stages influenced heavy metal uptake and distribution in maize crop grown on lead-acid battery waste contaminated soil. Journal of Environmental Chemical Engineering, 6: 4809-4819.

Akanbi W.B. (2002). Growth, nutrient uptake and yield of maize and okra as influenced by compost and nitrogen fertilizer under different cropping systems. Ph.D Thesis, University of Ibadan, pp. 222.

Antosiewicz D. \& Wierzbicka M. (1999). Localization of lead in Allium cepa L., cell by electron microscopy. Journal of Microscopy, 195: 139-146.

Ashraf M. \& Foolad M.R. (2007). Roles of glycine betaine and proline in improving plant abiotic stress tolerance. Environmental and Experimental Botany, 59: 206-216.

Ashraf M., Karim F. \& Rasul E. (2002). Interactive effects of gibberellic acid (GA3) and salt stress on growth, ion accumulation and photosynthetic capacity of two spring wheat (Triticum aestivum L.) cultivars differing in salt tolerance. Plant Growth Regulation, 36: 49-59.

Awoyemi V. \& Adejumo S.A. (2018). Seed germination and growth of maize (Zea mays L.) on lead contaminated soil in response to compost, exogenous proline and plant growth promoters in Ibadan, Nigeria. Nigerian Journal of Ecology, 17(2): 149-167.

Banu M.N.A., Hoque M.A., Watanabe-Sugimoto M., Matsuoka K., Nakamura Y., Shimoishi T. \& Murata Y. (2009). Proline and glycine betaine induce antioxidant defense gene expression and suppress cell death in cultured tobacco cell under salt stress. Journal of Plant Physiology, 166(2): 146-156.

Bates L.S., Wadren R.P. \& Teare I.D. (1973). Rapid determination of free proline for water stress studies. Plant Soil, 39: 205-207.

Bolan N.S., Ko B.G., Anderson C.W.N. \& Vogeler I. (2008). Solute interactions in soils in relation to bioavailability and remediation of the environment. In: $5^{\text {th }}$ International Symposium ISMOM 2008. $24^{\text {th }}-28^{\text {th }}$ November 2008, Pucón, Chile.

Cakmak I. \& Horst W.J. (1991). Effect of aluminium on lipid peroxidation, superoxide dismutase, catalase and peroxidase activities in root tips of soybean (Glycine max). Plant Physiology, 83: 463.

Camolesi M.R., Unemoto L.K., Sachs P.J.D., Roberto S.R., Sato A.J., Faria A.P., Rodrigues E.B. \& da Silva J.V. (2007). Semihardwood cuttings rooting of peach tree "Okinawa" under effect of lesion and indole butyric acid. Ciencia Rural, 37: 1805-1808. 
Chanda T., Debnath G.K., Hossain M.E., Islam M.A. \& Begm M.K. (2012). Adulteration of raw milk in the rural areas of Barisal district of Bangladesh. Bangladesh Journal of Animal Science, 41(2): 112-115.

Chen W., Provart NJ, Glazebrook J, Katagiri F., Chang H.S., et al. (2002). Expression profile matrix of Arabidopsis transcription factor genes suggests their putative functions in response to environmental stresses. Plant Cell, 14: 559-574.

Chen W.J. \& Zhu T. (2004). Networks of transcription factors with roles in environmental stress response. Trends in Plant Sciences, 9: 591-596.

Chen T.H.H. \& Murata N. (2011). Glycine betaine protects plants against abiotic stress: Mechanisms and biotechnological applications. Plant, Cell \& Environment, 34: 1-20.

Claussen W. (2005). Proline as a measure of stress in tomato plants. Plant Science, 43: 491-500.

Eun S.O., Youn H.S. \& Lee Y. (2000). Lead distrubs microtubule organization in the root meristem of Zea mays. Physiologia Plantarum, 110: 357-365.

Fleming M., Tai Y., Zhuang P. \& McBride M.B. (2013). Extrctability and bioavailability of Pb and As in historically Contaminated orchard soil: Effects of compost amendments. Environmental Pollution, 177: 90-97

Grieve C.M. \& Grattan S.R. (1983). Rapid assay for determination of water soluble quaternary ammonium compounds. Plant Soil, 70: 303-307.

Hanan A.A., Tale M.T., Abdelhamid M.G., Dawood R. \& Nassar M.A. (2013). Pre-sowing seed Treatment with Proline Improves some Physiological, Biochemical and Anatomical Attributes of Faba Bean Plants under Sea Water stress. Journal of Applied Sciences Research, 9(4): 2853-2867.

Hossain M.A., DaSilva J.A.T. \& Fajita M. (2011). Glyoxalase system and reactive oxygen species detoxification system in plants abiotic response and tolerance: an intimate relationship. In: Shanker A.K. \& Venketes-Warlu (Eds.) Abiotic stress in plantsmechanisms and Adaptations. IN TECH- Open Access Publisher, Rijeka Croatia, pp. 235-266,

Hossain M.A., Pukclai P., Teixeira J.A., da S. \& Masayuki F. (2012). Molecular mechanism of heavy metal toxicity and tolerance in plants: central role of glutathione in detoxification of reactive oxygen species and methylglyoxal and in heavy metal chelation. Journal of Botany, 2012: 37. [DOI: 10.1155/2012/872875]

Iqbal M. \& Ashraf M. (2013). Gibberellic acid mediated induction of salt tolerance in wheat plants: Growth, ionic partitioning, photosynthesis, yield and hormonal homeostasis. Environmental and Experimental Botany, 86: 76-85.

Ishii T., Soeno K., Asami T., Fujioka S. \& Shimada Y. (2010). Arabidopsis seedlings over-accumulated indole-3-acetic acid in response to aminooxyacetic acid. Bioscience, Biotechnology, and Biochemistry, 74: 2345-2347.

Islam M.M., Hoque M.A., Okuma E., Banu M.N., Shimoishi Y., Nakamura Y., et al. (2009). Exogenous proline and glycinebetaine increase antioxidant enzyme activities and confer tolerance to cadmium stress in cultured tobacco cells. Journal of Plant Physiology, 166: 1587-1597.

Julkunen-Titto R. (1985). Phenolic constituents in the leaves of northern willows: methods for the analysis of certain phenolics. Journal of Agricultural and Food Chemistry, 33: 213-217.

Kavi Kishor P.B., Sangam S., Amrutha R.N. et al., (2005). Regulation of proline biosynthesis, degradation, uptake and transport in higher plants: Its implications in plant growth and abiotic stress tolerance. Current Science, 88: 3.

Lattanzio V., Lattanzio V.M.T. \& Cardinali A. (2006). Role of polyphenols in the resistance mechanisms of plants against fungal pathogens and insects. In: Imperato F. (Ed.) Phytochemistry: Advances in research. Trivandrum, Herala, India: Research Signpost, pp. 23-67.

Magome H., Yamaguchi S., Hanada A., Kamiya Y. \& Oda K. (2004). Dwarf and delayed-flowering 1, a novel Arabidopsis mutant deficient in gibberellin biosynthesis because of overexpression of a putative AP2 transcription factor. Plant Journal, 37: $720-729$.

Martins L.L., Mourato M.P., Cardoso A.L., Pinto A.P., Mota A.M., Goncalves M.D.L.S. \& de Varennes A. (2011). Oxidative stress induced by cadmium in Nicotiana tabacum L.: Effects on growth parameters, oxidative damage and antioxidant responses in different plant parts. Acta Physiologiae Plantarum, 33: 1375-1383.

Gururani M.A., Mohanta T.K. \& Bae H. (2015). Current Understanding of the Interplay between Phytohormones and Photosynthesis under Environmental Stress. International Journal of Molecular Sciences, 16: 19055-19085.

Noreen S., Akhter M.S., Yaamin T. \& Arfan M. (2018). The ameliorative effects of exogenously applied proline on physiological and biochemical parameters of wheat (Triticum aestivum L.) crop under copper stress condition. Journal of Plant Interactions, 13(1): 221-230.

Nyyssölä A. \& Leisola M. (2001). Actinopolyspora halophila has two separate pathways for betaine synthesis. Archives of Microbiology; 176: 294-300.

Ogundiran M.B. (2007). Assessment and chemical remediation of soil contaminated by lead-acid battery waste in Lalupon, Oyo State, Nigeria, (Ph.D. dissertation). University of Ibadan, Ibadan, Nigeria.

Prasad K.V.S.K. \& Saradhi P.P. (2004). Enhanced tolerance to photoinhibition in transgenic plants through targeting of glycine betaine biosynthesis into the chloroplasts. Plant Science, 166: 1197-1212.

Rennevan H., Tony R.H., Abir A., Andy J.M., Mike L.J. \& Sabeha K.O. (2007). Remediation of Metal contaminated soil with mineral amended composts. Environment Pollution, 150: 347-354.

Sakamoto A. \& Murata N. (2002). The roles of glycine betaine in the protection of plants from stress: clues from transgenic plants. Plant, Cell and Environment, 25: 163-171.

Salati S., Quadri G., Tambone F. \& Adani F. (2010). Fresh organic matter of municipal solid waste enhances phytoextraction of heavy metals from contaminated soil. Environmental Pollution, 158:1899-1906. 
Sandalio L.M., Dalurzo H.C., Gomez M., Romero-Puertas M.C. \& Del Rio L.A. (2001). Cadmium-induced changes in the growth and oxidative metabolism of pea plants. Journal of Experimental Botany, 52: 2115-2126.

Sarropoulou V.N., Therios I.N. \& Dimassi-Theriou K.N. (2012). Melatonin promotes adventitious root regeneration in in vitro shoot tip explants of the commercial swet cherry rootstocks CAB-6P (Prunus cerasus L.), Gisela 6 (P. cerasus X P. canescens), and MXM 60 (P. avium X P. mahaleb). Journal of Pineal Research, 52: 38-46.

Sarvesh A., Anuradha M., Pulliah T., Reddy T.P. \& Kavi Kishor P.B. (1966). Salt stress and antioxidant response in high and low proline producing cultivars of niger, Guizotia abyssinica (L.F) Cass. Indian Journal of Experimental Biology, 34: 252-2565.

Sharma P. \& Dubey R.S. (2005). Pb toxicity in plants. Brazilian Journal of Plant Physiology, 17: 35-52.

Sharma P. \& Dubey R.S. (2007). Involvement of oxidative stress and role of antioxidative defense system in growing rice seedlings exposed to toxic concentration of aluminium. Plant Cell Reports, 26(11): 2027-2038.

Shen Y.G., Du B.X., Zhang W.K., Zhang J.S. \& Chen S.Y. (2002). AhCMO, regulated by stresses in Atriplex hortensis, can improve drought tolerance in transgenic tobacco. Theoretical and Applied Genetics, 105: 815-821.

Siedlecka A. \& Krupa Z. (2002). Functions of enzymes in heavy metal treated plants. In: Prasad M.N.V. \& Kazimierz S. (Eds.) Physiology and biochemistry of metal toxicity and tolerance in plants. Kluwer, Netherlands, pp. 314-3177.

Siedlecka A. (1995). Some aspects of interactions between heavy metals and plant mineral nutrients. Acta Societatis Botanicorum Poloniae, 64: 265.

Siedlecka A. \& Krupa Z. (1999). Cd/Fe interaction in higher plants - its consequences for the photosynthetic apparatus. Photosynthetica, 36: 321.

Singh A. \& Khan M.A. (2009). Comparative effect of IAA, IBA and NAA on rooting of hardwood stem cuttings of Celtis australis Linn. Range Management and Agroforestry, 30: 78-80.

Souguir D., Ferjani E., Ledoigt G. \& Pascale G. (2011). Sequential effects of cadmium on genotoxicity and lipo-peroxidation in Vicia faba roots. Ecotoxicology, 20: 329-336.

Strader L.C., Culler A.H., Cohen J.D. \& Bartel B. (2010). Conversion of endogenous indole-3-butyric acid to indole-3-acetic acid drives cell expansion in arabidopsis seedlings. Plant Physiology, 153: 1577-1586.

Tejada M.A. \& Gonzalez J.L. (2006). Crushed cotton gin compost on soil biological properties and rice yield. European Journal of Agronomy, 25: 22-29.

Takahama U. \& Oniki T. (2000). Flavonoid and some other phenoilcs as substrates of peroxidase physiological significance of the redox reactions. Journal of Plant Research, 113: 301.

Tsegay B.A. \& Andargie M.J. (2018). Seed Priming with Gibberellic Acid (GA3) Alleviates Salinity Induced Inhibition of Germination and Seedling Growth of Zea mays L., Pisum sativum var. abyssinicum A. Braun and Lathyrus sativus L. Journal of Crop Science and Biotechnology, 21(3): 261-267.

Vanrensburg L., Kruger G.H.J. \& Kruger R.H. (1993) Proline accumulation as drought tolerance selection criterion: Its relationship to membrane integrity and chloroplast ultrastructure in Nicotiana tabacum L. Journal of Plant Physiology, 141: 188-194.

Velikova V., Yordanov I. \& Edreva A. (2000). Oxidative stress and some antioxidant systems in acid rain treated bean plants: Protective role of exogenous polyamines. Plant Science, 151: 59-66.

Verma S. \& Dubey R.S. (2003). Pb toxicity induces lipid peroxidation and alters the activities of antioxidant enzymes in growing rice plants. Plant Science, 64: 645-655.

Wang Y., Du S.T., Li L.L., Huang L.D., Fang P., Lin X.Y., Zhang Y.S. \& Wang H.L. (2009). Effect of $\mathrm{CO}_{2}$ elevation on root growth and its relationship with indole acetic acid and ethylene in tomato seedlings. Pedosphere, 19: 570-576.

Yuan L. \& Xu D. (2001). Stimulation effect of gibberellic acid short-term treatment on leaf photosynthesis related to the increase in Rubisco content in broad bean and soybean. Photosynthesis Research, 68: 39-47.

Zhang C., Tanabe K., Tani H., Nakajima H., Mori M., Itai A. \& Sakuno E. (2007). Biologically active gibberellins and abscisic acid in fruit of two late-maturing Japanese pear cultivars with contrasting fruit size. Journal of the American Society for Horticultural Science, 132: 452-458.

Zhang C.S., Lu Q. \& Verma D.P.S. (1997). Characterization of $\Delta^{1}$-pyrroline-5-carboxylate synthetase gene promoter in transgenic Arabidopsis thaliana subjected to water stress. Plant Science, 129: 81-89.

Zhang R., Zhang X., Wang J., Letham D.S., McKinney S.A. \& Higgins T.J.V. (1995). The effect of auxin on cytokinin levels and metabolism in transgenic tobacco tissue expressing an ipt gene. Planta, 196: 84-94. 